\title{
Three cases report of resistance to thyroid hormone and the genetic mutation of these patients and their family members
}

\author{
Yi Gu, Chun-xiu Gong ${ }^{*}$, Qian Dong, Chang Su \\ From 7th APPES Biennial Scientific Meeting \\ Nusa Dua, Bali. 14-17 November 2012
}

\begin{abstract}
Aims
We report the clinical characteristics and the genetic analysis of their family members of 3 cases. Resistance to thyroid hormone (RTH), a dominant inherited syndrome and it is usually due to mutations located at the ligandbinding domain and adjacent hinge region of the thyroid hormone receptor $\beta$ (TR $\beta$ ).
\end{abstract}

\section{Methods}

We describe patients' clinical features, biochemical and hormones level such as thyroid function tests (TFTs), imagination data. We also detected the TFTs of his family members as well. Direct DNA sequencing of the TR $\beta$ gene was done for all those with abnormal TFTs.

\section{Results}

The RTH children had goiter, irritability, aggressiveness, and hyperhidrosis. The TFTs showed high levels of circulating free thyroid hormones (FT4 and FT3) and normal or high thyroid-stimulating hormone (TSH) concentrations. All of these patients used bromocriptine, and then clinical presentations got improved obviously without obvious advert effect. From these three patients and their family members we identified a novel missense mutation, A317D, located in exon 9 of the gene of a boy patient and his mother, but his mother showed no any clinical presentation. However, we didn't have any abnormal finding in for other patients and their parents.

\section{Conclusion}

The RTH children had goiter, irritability, aggressiveness, and hyperhidrosis. The TFTs showed high levels of

\footnotetext{
The Capital medical University, Beijing Children's Hospital, Beijing 100045,
} China

(c) $2013 \mathrm{Gu}$ et al; licensee BioMed Central Ltd. This is an Open Access article distributed under the terms of the Creative Commons Attribution License (http://creativecommons.org/licenses/by/2.0), which permits unrestricted use, distribution, and reproduction in any medium, provided the original work is properly cited. circulating free thyroid hormones (FT4 and FT3) and normal or high thyroid-stimulating hormone (TSH) concentrations. Fund a novel mutation in the TR $\beta$ in one patient and his mother. This research verified the phenomena that there is a heterogeneous within the same mutation of RTH patients. All of these patients used bromocriptine, and then clinical presentations got improved obviously without obvious advert effect.

Published: 3 October 2013

doi:10.1186/1687-9856-2013-S1-P155

Cite this article as: Gu et al.: Three cases report of resistance to thyroid hormone and the genetic mutation of these patients and their family members. International Journal of Pediatric Endocrinology 20132013

(Suppl 1):P155.

Submit your next manuscript to BioMed Central and take full advantage of:

- Convenient online submission

- Thorough peer review

- No space constraints or color figure charges

- Immediate publication on acceptance

- Inclusion in PubMed, CAS, Scopus and Google Scholar

- Research which is freely available for redistribution
C Biomed Central 